\title{
Physico-Chemical Characterization of Arbutus Unedo L. From kabylian Region (Northern Algeria)
}

\author{
Tounsia Aksil-Abbas ${ }^{1 *}$, Moussa Abbas ${ }^{1}$ and Salem Benamara ${ }^{2}$ \\ ${ }^{1}$ Laboratory of Soft Technologies and Biodiversity (LTDVPMB), University M'hamedBougara of Boumerdès, Algeria \\ ${ }^{2}$ Research Laboratory in Food Technology (LRTA), University M'hamed Bougara, Algeria
}

Received: December 12, 2017; Published: December 15, 2017

*Corresponding author: Tounsia Aksil-Abbas, Laboratory of Soft Technologies and Biodiversity (LTDVPMB), Faculty ofSciences, University M'hamedBougara of Boumerdès, 35000, Algeria

\begin{abstract}
The fruits of the strawberry tree (Arbutus unedo L.) are consumed mainly as processed product, but may be a good source of antioxidants if consumed as fresh fruit. The presented work aims to evaluet some of its physicochemical parameters, including X-ray diffraction (XRD) properties, crude fiber, titrable acidity, etc.
\end{abstract}

Keywords: Arbutus unedo L; Caracterisation; Physicochemical

Abbreviations: FA: Arbutus fruit; XRD: X-Ray Diffraction

\section{Introduction}

Arbutus berries (Arbutus unedo L.) is a Mediterranean typical tree which fruit is generally not consumed in fresh form but after processing [1]. Like other plants which are fitted with wonderful defense system assured by various biopharmaceuticals [2], the berries are also known to be used in folk medicine as antiseptic, diuretic and laxative [3] Moreover, Ruiz-Rodríguez et al. [4] having earlier supported that the higher antioxidant potential of the arbutus berries may be due to the activity of various bioactive components including vitamin C. So, considering dietary ingredient any herbal or botanical material containing vitamins and minerals, arbutus berries may be repertories as a dietary supplement. Arbutus unedo (Ericaceae) part of the range of Algeria medicinal plants [5]. The Arbutus fruit (FA) is poorly exploited, not very well-known from point of view nutritional and industrial by the population Algerian and its consumption remains seasonal. In this context, the present work main purpose the physico-chemical study powder freezedried (PL) of Algerian FA (Arbutus unedo L.).

\section{Materials and Methods}

Ripe Arbutus berries were picked in Kabylian region (northern Algeria) in 2017. The fruit is submitted to freeze drying at 109 $\mathrm{K}$ (4.5 Pa) during 2 days. The dried product is then ground and sieved (sieve of type Euromatest-Sintoo, NFX11-501) to obtain homogeneous powder (LP) which is kept in closed glass flask at 277K. The general chemical parameters of LP A. unedo berries, namely; crude fiber [6], titrable acidity (with $\mathrm{NaOH}, 0.1 \mathrm{~N}$ ), pectin
[7], ash and Acid-Insoluble Ash [8] were evaluated. The electrical conductivity of $20 \%$ LP solution in distilled water was measured at $20{ }^{\circ} \mathrm{C}\left(\mathrm{mScm}^{-1}\right)$; the lipid was determined, using a Soxhlet apparatus. The X-ray diffraction (XRD) of LP was investigated using diffractometer (Panalytical Xpert Pro ®.)

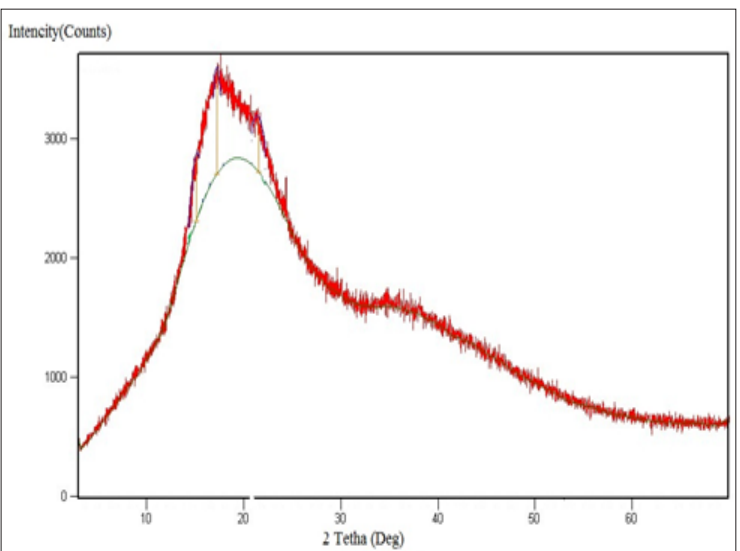

Figure 1: X-ray diffraction patterns of powders freeze dried arbutus berries.

\section{Results and Discussion}

The different quality parameters of LP are summarized in Table 3. Crude fiber of LP is comparable to that reported by RuizRodríguez et al. [4] and is less than that reported by Özcan and Hacıseferogulları, [9] for fresh strawberry tree fruits $(6.4 \mathrm{~g} / 100 \mathrm{~g}$ 
of cellulose, $2.93 \mathrm{~g} / 100 \mathrm{~g}$ soluble fibers respectively). The titratable acidity is close to that indicated in the literature $0.4 \%$ [10], On the other hand, it is less than that given by Celikel et al. [11] $(0.48$ 1.24 and $0.8-1.59 \%$ respectively) for the Turkish variety electric conduvtivity is greater than that calculated by Ulloa et al. [12] $\left(0.643 \mathrm{mScm}^{-1}\right)$ for strawberry tree (Arbutus unedo L.) honey. The XRD pattern of LP powder is presented in Figure 1. A broad band with very weak peaks, characteristic of amorphous forms, is observed in the pattern indicating the presence of amorphous sugar obtained by freeze-drying fruits berry. Furthermore, the amorphous characteristics are clearly reported on different dried mango powders [13] and fluidize-dried gum extracted from the fresh fruits of Abelmoschus esculentus [14] (Table 1) \& (Figure 1).

Table 1: Physicochemical characterization of LP.

\begin{tabular}{|c|c|}
\hline Parameter & Value \\
\hline Crude fiber (\%) & $4.440 \pm 0.125$ \\
\hline Titrable acidity (\%) & $0.210 \pm 0.010$ \\
\hline Pectin(\%) & $2.456 \pm 0.034$ \\
\hline Total ash & $3.910 \pm 0.030$ \\
\hline Acid-Insoluble Ash (\%) & 0.510 \\
\hline Lipid (\%) & $0.801 \pm 0.080$ \\
\hline Electrical conductivity (mS.cm-1) & $2.550 \pm 0.050$ \\
\hline
\end{tabular}

\section{Conclusion}

The results showed that all physicochemical parameters were comparable to those the literature.

\section{References}

1. Simonetti MS, Damiani F, Gabrielli L, Cossignani L, Blasi F, et al. (2008) Characterization of cylglycerols in Arbutus unedo L. seeds. Italian Journal of Food Science 20: 49-56.

2. Rahman M Sh (2007) Allicin and other functional active components in garlic: Health benefits and bioavailability. International Journal of Food Properties 10(2): 245-268.

3. Pallauf K, Rivas-Gonzalo JC, Del Castillo, Cano MP, Pascual-Teresa S (2008) Characterization of the antioxidant composition of strawberry tree (Arbutus unedo L.) fruits. Journal of Food Composition and Analysis 21(4): 273-281.

4. Ruiz-Rodríguez BM, Morales P, Fernández-Ruiz V, Sánchez-Mata MC, Cámara M, et al. (2011) Valorization of wildstrawberry-tree fruits (Arbutus unedo L.) through nutritional assessment and natural production data. Food Research International 44: 1244-1253.

5. Abbas-Aksil T, Banamara S (2015) Modeling of the Dissolution Kinetics of Arbutus Wild Berries-Based Tablets as Evaluated by Electric Conductivity. Sains Malaysiana 44(2): 301-308.

6. Yaiche Achour Hafsa, Doumandji Amel, Sadi Samia, Saadi Sidahmed (2014) Evaluation of nutritional and sensory properties of bread enriched with spirulina. Annals Food Science and Technology pp. 270275 .

7. Multon JL Bizot, H Martin G (1991) Mesure de l'eau adsorbée dans les aliments, Techniques d'analyse et de contrôle dans les industries agroalimentaires, (2 ${ }^{\text {nd }}$ Edition), Lavoisier Tec and Doc, Paris, p. 158-200.

8. Singh MP, Sharma CS (2010) Pharmacognostical Evaluation of Terminalia Chebula fruits on different market samples. International Journal of Chem Tech Research 2(1) : 57-61.

9. Özcan MM, Hacıseferoğulları H (2010) The Strawberry (Arbutus unedo L.) fruits: Chemical composition, physical properties and mineral contents. Journal of food Engineering 113: 1022-1028.

10. Celikel G, Demirsoy L, Demirsoy H (2008) the strawberry tree (Arbutus unedo L.) selection in Turkey. Scientia Horticulturae 118: 115-119.

11. Emeje M, Isimi Ch, Byrn S, Fortunak J, Kunle O, et al. (2010) Extraction and Physicochemical Characterization of a New Polysaccharide Obtained from the Fresh Fruits of Abelmoschus Esculentus. journal of pharmaceutical research 10(2): 237-246.

12. Ulloa PA Maia M, Brigas AF (2015) Physicochemical Parameters and Bioactive Compounds of Strawberry Tree (Arbutus unedo L.) Honey. Journal of Chemistry p. 10.

13. Niimura H, Yokoyama T, Kimura S, Matsumoto Y, Kuga S (2010) AFM observation of ultrathin microfibrils in fruit tissues. Cellulose 17(1): 1318.

14. Vega-Galvez A, Miranda M, Diaz LP, Lopez L, Rodriguez K, et al. (2010) Effective moisture diffusivity determination and mathematical modeling of the drying curves of the olive-waste cake. Bioresour Technology 101(19): 7265-7270.

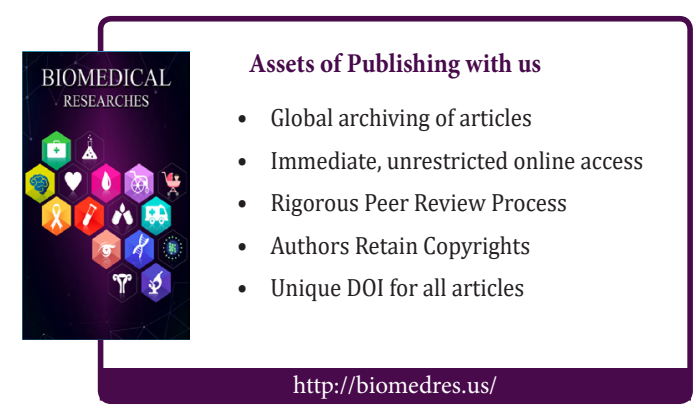

